\title{
Review
}

\section{In the Marxian workshops: Producing subjects}

\author{
Sandro Mezzadra \\ Rowman and Littlefield, London, 2018, xvii + 143pp., \\ ISBN: 978-1786603609
}

Contemporary Political Theory (2020) 19, S255-S258. https://doi.org/10.1057/s41296019-00366-4; published online 12 November 2019

'It has never been easy to think and write about Karl Marx', Hannah Arendt once remarked, alluding to the difficulties of disentangling the dangerous lives Marx's thought led (and continues to lead) (2002, p. 273). Sandro Mezzadra's book In the Marxian Workshops takes the strong doubts about the fruitfulness of a final disentanglement of Marx's thought as a point of departure. Seeing no use in any attempt to articulate Marxism as a 'system of thought capable of providing an overall explanation of the world' (p. 2), Mezzadra offers a creative and productive reading that explores the Marxian archives, guided by 'recent struggles, achievements and theoretical developments' (p. x). While Marx's oeuvre is thus turned into a 'workshop' for present concerns and struggles, this is done by tracing in his works the poststructuralist theme of the production of subjectivity. The subject is understood in this context as a relation of forces rather than a transcendental capacity. Mezzadra then zooms in on various forces that shape subjects - history, capital, labour, class, gender, race - as they show up in Marx's texts and in the present.

In keeping with the spirit of this book, we might want to understand the 'forces' that shaped it. One of the most important intellectual influences shaping this work is the Italian 'autonomist' Marxist tradition with which Mezzadra is affiliated. Employing unorthodox readings of Marx and engaging with French poststructuralist thought, autonomist Marxists (the most well-known being Michael Hardt and Antonio Negri) share an emphasis on the relative autonomy of the working class vis-à-vis capital, paired with an interest in the transformation of work and labour since the 1970s and the problematic of 'composing' a class across this splintered field of labour and various other struggles. The question of the 'production of subjectivity' - the way in which human beings are constituted through structures of language and power - is then not exclusive to Mezzadra, as it is a recurring motif through autonomist thought. If the meanings of the traditional political subject have been exhausted or co-opted (citizen, worker, militant etc.),

(C) 2019 Springer Nature Limited. 1470-8914 Contemporary Political Theory Vol. 19, S4, S255-S258 
then what is important - the argument goes - is questioning the way subjectivity is 'produced' in order to find ways in which it can also be transformed.

Most of these elements - a concern with political subjectification, class struggle and a shift to the terrain of subjectivity for critique - are all present in the ten short chapters of The Marxian Workshops. The first two chapters outline Mezzadra's methodology: reading Marx beyond Marxism and reading the theme of the production of subjectivity through his oeuvre in a consciously anachronistic way (p. $\mathrm{xviii)}$. The rest of the eight chapters are short essays, proceeding in a chronological fashion through Marx's oeuvre, offering fragmentary readings through specific themes and concerns - but always with the production of subjectivity as a constant focus. They touch upon the relationship between politics and philosophy, the degree of freedom the subject has in the making of history, the concepts of living labour and labour power, the concept of class in relation to race and gender and the relationship of colonialism to the history of capitalism.

There are two problems that Mezzadra highlights throughout the book, which can be seen as two sides of the same coin. One of these is the 'extractive' nature of contemporary capitalism (a notion developed elsewhere with Brett Neilson (2013)). With this he refers to the tendency of capitalism to relentlessly overcome frontiers for the extraction of value, be these actually existing frontiers such as borders, or cultural frontiers found for example in pre-capitalist societies, or areas of life and social existence not yet subject to capitalist valorisation. The other is the construction of a 'politics of liberation' (p. xii) or class struggle against these extractive processes, one that is able to traverse the diversity and heterogeneity of struggles wound up with this process of extraction and valorisation, without suppressing their particularity.

While Mezzadra does not have clear-cut answers to these problems, the book is at its most exciting when he tackles them directly. For example, in his interpretation of class as fundamentally co-constituted by race and gender struggles (p. 68), and in the essay on 'Marx in Algiers', where the multilinear view of history found in the writings of Marx's last years is exposed (ch. 10). However, while the author raises our expectation that the book will 'identify the specific character of the relations of exploitation and domination in contemporary capitalism' (p. xix) and combine close readings of Marx with contemporary issues, a different kind of project unfolds. Rather, what the book does is to provide a reading of Marx that could allow for such an identification, as well as allow for a tackling of the contemporary concerns noted. It provides the basis for these understandings but stops short of performing them. Admittedly Mezzadra states once that the book is 'meant to enable a reading of Marx's texts up to the challenges that shape our present' (p. xi, emphasis added). However, shedding some more light on the concrete transformations that he is convinced that Marxism needs to take into account would have been welcome. 
The main issues with the book, however, are its extreme density and the opaque usage of the phrase 'production of subjectivity'. While Mezzadra warns the reader that this is no introduction to Marx's thought (p. xix), this is an understatement, also with regards to the other literature he employs. The reader is presupposed to be familiar with most, if not all of Marx's oeuvre as well as that of Foucault, be wellversed in debates around the production of subjectivity and have a command of key Italian autonomia concepts, as there is little in the way of contextualization. Even when one is familiar with all of the literatures employed, the way the jargon around subjectivity and its 'production' is used is often confusing.

While for Foucault the question of the 'production of subjectivity' was a mode of investigation into the 'modes of objectification which transform human beings into subjects' (Foucault, 2002, p. 326), it is unclear what this phrase means for Mezzadra, apart from the truism that subjects are constituted by historical relations of power, while also entertaining some freedom in the making of that history (p. 29). It is unclear, for example, what exactly is meant by the 'subjectivity of capital', or the 'subjectivity of labour' (p. 41) in this context - perhaps the subjective inflection that the capital-labour relationship gives to either the capitalist or labourer? Although there is a chapter dedicated explaining 'the production of subjectivity' (ch. 2), this is done in such a fashion that, if one is not already familiar with the perspective, it will be quite tough to discern the differences, for example, between subjection and subjectivation. While no doubt born out a desire to keep the book short and snappy, one is left wondering what audience the book is trying to address - besides the already initiated - and whether the aim to connect Marx's thought to a variety of contemporary struggles is not neglected as a consequence.

In terms of style, one sometimes gets the impression that subjectivity comes rolling off the factory line in The Marxian Workshops. Subjectivity is 'modified' (p. 77) and 'devices' are used to 'produce' subjectivity (p. 76), 'figures' of subjectivity (p. 38) or the 'field of modern subjectivity' (p. 61). While 'device' is commonly used to translate the French dispositif, the productivist language used to refer to processes of becoming a subject that are beyond the reach of any particular 'producer' are unfortunate. Although Mezzadra stresses the importance of the freedom subjects have in transforming themselves and the world (pp. 30, 77, 96), the language used suggests a substantialist conception of subjectivity, according to which subjectivity is a thing that can be produced and modified. While this is perhaps not the author's intention, this implied account of subjectivity seems somewhat crude, if not undesirable.

Lastly, if subjectivity is 'produced', even acknowledging the subject's own contribution to this production, the reader is left in the dark regarding the question that should perhaps become paramount, namely: how is subjectivity produced? If subjectivity is stripped of its transcendental basis as its claim to truth and is 'produced' through socio-historical forces, then is it not to these forces themselves that we should turn? Should we not pay most attention exactly to those

(C) 2019 Springer Nature Limited. 1470-8914 Contemporary Political Theory Vol. 19, S4, S255-S258 S257 
'mechanisms' of subjectification and their histories? Understanding the limited scope and particular aim of the book, there is nonetheless a curious tension between juxtaposing Marx with the 'production of subjectivity' and remaining at such a level of abstraction as to render these forces largely outside the picture. While the book spins a theoretically rich and dense fabric out of this juxtaposition, deftly and expertly threading together a dazzling range of literatures from various fields, it is mainly further questions and bedazzlement that the reader is left with - which in this case is perhaps the book's strength as much as its weakness.

\section{References}

Arendt, H. (2002) Karl Marx and the tradition of western political thought. Social Research: An International Quarterly 69(2): 273-319.

Foucault, M. 2002. In Power: Essential Works of Foucault, 1954-1984., Vol. 3, ed., J.D. Faubion. London: Penguin.

Mezzadra, S. and Neilson, B. (2013) Border as Method, or, the Multiplication of Labor. Durham: Duke University Press.

Publisher's Note Springer Nature remains neutral with regard to jurisdictional claims in published maps and institutional affiliations.

Thijs Keulen

University of Edinburgh, Edinburgh EH8 9YL, Scotland, UK t.keulen@sms.ed.ac.uk 